\title{
Toward Engaged Scholarship: Knowledge Inclusivity and Collaborative Collection Development between Academic Libraries and Archives and Local Public Communities
}

\section{Amanda Y. Makula and Laura S. Turner}

In Open and Equitable Scholarly Communications, ACRL calls for more diverse and inclusive collection development (CD) by academic libraries and archives. Meanwhile, higher education is increasingly committing to community-engaged scholarship. This study investigated the extent to which academic libraries and archives are collecting, curating, and/or preserving knowledge produced by their local public communities. Researchers administered an electronic survey to relevant listservs and conducted follow-up interviews to develop a case study of one library's efforts. Ninety of the initial 118 survey respondents $(76 \%)$ indicated that their academic library intentionally collects, curates, and/or preserves materials created or owned by the local public community, with a majority working with minority or underrepresented populations in their communities. Respondents also reported working with unpublished archival material more than twice as often as nonarchival/circulating material, reflecting academia's movement toward greater inclusion of traditionally excluded voices in the scholarly record. Additional research is needed for a host of issues raised by this work, in particular the relationship between university-community collection development and student learning. Library leaders can promote university-community engagement and knowledge diversity by incorporating local community knowledge into their collection development commitments and practices and tying this work to the parent institution's strategic plan.

"...the world is not separated into the scholarly and the ordinary."1

\section{Introduction}

"Collection development necessarily responds to trends in academia, bringing forward new frameworks that shift the whats, whys, and hows of acquiring library materials," write Debo-

\footnotetext{
* Amanda Y. Makula is Associate Professor and Digital Initiatives Librarian and Laura S. Turner is Associate Professor and Head of Collections, Access, and Discovery at the University of San Diego, email: amakula@sandiego.edu, lauraturner@sandiego.edu. The authors wish to thank ACRL for their funding support; the interview participants for sharing their time and experiences; and the peer reviewers for their feedback and recommendations. Special thanks to our families for their encouragement and support. (C2022, Amanda Y. Makula and Laura S. Turner, Attribution-NonCommercial (https://creativecommons.org/licenses/by-nc/4.0/) CC BY-NC.
} 
rah K. Boudewyns and Shannon L. Klug. ${ }^{2}$ Helen N. Levenson agrees, arguing that collection development, and specifically CD policies, should be flexible and responsive, adapting to the institution's unique mission and vision and ever-evolving to reflect local context and priorities as well as changes in the larger information landscape. ${ }^{3}$ In a study by Tony Horava and Michael Levine-Clark, the authors found support for an approach to collection building that is "nimble in responding to changes in focus for the university." 4 These authors signal growing consensus that collection development should be viewed holistically, as intimately interconnected to the academic enterprise as a whole: as higher education changes, so too should academic collections and collection-building practices. The key question then becomes: what are those changes? This article identifies significant trends within academia toward greater knowledge inclusivity and community-engaged scholarship and argues that, by broadening the scope of their collections to include materials produced by their local public communities, academic libraries and archives have a tangible way to support both movements.

In a paper prepared for the Canadian Commission for UNESCO, titled "Open Science Beyond Open Access: For and with communities: A step towards the decolonization of knowledge," Leslie Chan et al. trace a gradual opening of science and scholarship beginning in the last half of the twentieth century: from primarily exclusive knowledge systems - Western, male, capitalist, and empirical - to broader, more inclusive ones, encompassing indigenous, feminist, communal, and experiential ways of knowing. ${ }^{5}$ This movement, often described in the literature with terms such as knowledge democratization or decolonization, cognitive or epistemological justice, and participatory or community-engaged research, calls for the academy "to restore the knowledge that has been erased or silenced in the current system" by broadening the canon of knowledge to include contributions from those who have been excluded historically. ${ }^{6}$ In addition to the rapid growth of research addressing these movements, there is concrete evidence of their influence in the form of "engaged scholarship" within higher education, defined by Brown University's Swearer Center as:

...the co-creation of knowledge that shifts the position of students and community groups from knowledge consumers to knowledge producers and partners in problem-solving. Engaged scholarship is the generation of new knowledge through the combining of academic knowledge and community-based knowledge, eliminating a hierarchy of knowledge and a one-way flow of knowledge outward from the college or university ... [and] the recognition that in certain circumstances the expert will be a non-credentialed, nonacademic collaborator. ${ }^{7}$

Engaged scholarship is not new. It has roots in the idea of multiversity, envisioned by Paul Wangoola two decades ago as a "community knowledge bank" where modern and indigenous knowledge come together in synthesis to address humanity's greatest challenges. ${ }^{8}$ Wangoola distinguishes the multiversity from a university "insofar as it recognizes that the existence of alternative knowledges is important to human knowledge as a whole." ${ }^{9}$ In other words, the body of knowledge, and thus human progress, is strengthened by contributions from those outside the academy. Building new knowledge by cultivating close relationships between universities and local communities is steadily gaining momentum. "Over the past three decades, urban university-community partnerships have moved from dispersed and provisional ad hoc relationships to intentional and systematic institutional commitments," says 
Dr. Joshua Yates, current Fellow and former Research Director of the Thriving Cities Lab at the Institute for Advanced Studies and Culture (IASC).$^{10}$ The Carnegie Foundation has noted this trend and now offers a "Community Engagement Classification" to institutions that provide evidence of substantial commitment to "collaboration ... [with] their larger communities (local, regional/state, national, global) for the mutually beneficial exchange of knowledge and resources in a context of partnership and reciprocity." 11 As of this writing, 360 institutions carry the designation, many of whose institutional strategic plans prioritize community engagement partnerships. ${ }^{12}$ The Field Guide for Urban University-Community Partnerships, a national scan and working kit to advance university-community engagement, describes a situation in which institutions are increasingly looking for ways to "integrate, and to some extent redirect, community engagement and partnership across the entire institution."13

Enter the academic library and archive. As new definitions of knowledge and commitments to engaged scholarship revolutionize academia, academic libraries and archives have the opportunity to join and shape these conversations, particularly through their collections and collection development practices. The pivotal Association of College and Research Libraries' (ACRL) publication Open and Equitable Scholarly Communications: Creating a More Inclusive Future outlines connections between greater equity and diversity in knowledge construction and academic libraries and archives' collection development decisions, asking them to revisit "...what content is deemed important enough to be collected and preserved." 14 The authors devote a section ("Creating More Representative and Open Collections") to identifying research that is needed to "prioritize developing collections that better represent a broader range of scholars and scholarship."15 For example, they ask: "Are there nonwritten or otherwise nontraditional cultural heritage works being produced locally that should be acquired?"16

Academic libraries and archives have an opportunity to connect these questions to their own collections and collection building practices, to explore how to "work collaboratively to ensure inclusive collection and interpretation approaches, working with and for underrepresented communities ...[on] the identification and preservation of significant local knowledge."17 While the library literature contains individual, isolated examples of academic libraries and archives actively partnering with their local public communities to collect, curate, and/or preserve local forms of knowledge, particularly by members of historically underrepresented groups, to date there appears to be no national scan or landscape analysis. This study, selected for and generously funded by an ACRL Scholarly Communications Research Grant, sought to identify whether, how, and on what scale this work is happening, what drives or hinders it, and what it looks like in different institutional settings.

\section{Literature Review}

While this study concentrated on the United States, examples of libraries and archives outside the US provide inspiration for this work. In "Knowledge Exchange and Community Engagement: An Academic Library Perspective," Sidorko and Yang detail a host of efforts by the University of Hong Kong Libraries to engage both local communities and global society, driven in part by their parent institution's strategic priority for knowledge exchange, defined as "engaging, for mutual benefit, with business, government or the public to generate, acquire, apply and make accessible the knowledge needed to enhance material, human, social, cultural and environmental well-being." ${ }^{18}$ In particular, the "Hong Kong Memory Project" sought to preserve the city's collective memory and cultural heritage through the curation 
and presentation of oral histories in an online repository, to ultimately "serve as a major community resource for all Hong Kong people and those with interests in Hong Kong history, architecture, culture, customs, etc." 19

In Indonesia, the library at Petra Christian University launched the Surabaya Memory (SM) Project by collaborating with individuals and groups external to the campus. An early goal of the project was to collect and digitally preserve in the library's institutional repository the city's historical and cultural heritage materials; later, this partnership blossomed into additional outreach such as exhibitions, educational activities, and events held in local communal spaces like malls. ${ }^{20} \mathrm{SM}$ eventually led also to the city's planning department sharing public documents and government reports, and to the library's increased digitization and cataloging work. In "Leadership Role of an Academic Library in Community Outreach: Surabaya Memory Project," Toong Tjiek Liauw asserts that SM has helped define the institution as an "engaged university," ${ }^{21}$ which Westney characterizes as one that fosters "dynamic partnerships ...with external constituencies to advance knowledge while building community through collaboration." ${ }^{22}$ In the case of SM, the project also elevated the status of the library within its parent institution. The knowledge generated by the university-community interactions came full circle and was integrated into the university's academic curriculum by providing course assignments and applied service-learning opportunities. ${ }^{23}$

The "Chinese Canadian Stories Project," led by the University of British Columbia Library, sought to unearth the important but often under- and misrepresented contributions of Chinese immigrants to Canadian history. ${ }^{24}$ The library welcomed community members and groups, such as the Gee How Oak Tin clan association, to share their family histories and expertise through digitization workshops and translation of primary sources. Another Canadian venture, the Digital Archives and Marginalized Communities Project (DAMC) at the University of Manitoba, used a participatory approach with community stakeholders to create databases documenting missing and murdered indigenous women, sex worker communities, and the legacy of Indian residential schools in Canada. ${ }^{25}$ Collection development efforts, "driven by priorities established in conjunction with community partners," included public records in the form of both print and web media, ephemera, commemorative initiatives, informational pamphlets, images, and the like alongside academic publications. ${ }^{26}$ The communities' involvement was all-encompassing, beyond "typical processes such as collection development, appraisal, arrangement, and description [to] ...planning the digital archives itself, controlling all aspects of design, functionality, and appearance," and even hiring community members to serve as consultants. ${ }^{27}$ This participatory, collective ownership approach was made possible only by building deep relationships, open communication, and trust among community, activist, and academic partners and by practicing sensitivity to access and privacy concerns.

Closer to home, we find scattered examples in the published literature of universitycommunity collaborative collection development within the United States. The University of Louisville Archives and Special Collections has a collection development plan that specifically includes "a focus on documenting the greater Louisville area ... [and] reflects the University of Louisville's commitment to ...community engagement." ${ }^{28}$ The Louisville Underground Music Archives (LUMA) project intentionally incorporated community members' knowledge and input through community donation days, community-supplied metadata, and an advisory board with representation from members in the local music scene. ${ }^{29}$ Boston's Northeastern University Library's Archives and Special Collections Department also worked with community 
advisors to collect histories from the city's "African American, Chinese, Latino, and gay and lesbian communities" in an effort to diversify their collections, bring forth underrepresented perspectives, and counter dominant narratives in mainstream media. ${ }^{30}$ Another project guided by an advisory board is the Gi-gikinomaage-min, a collaboration between Grand Valley State University Libraries and the Native American community of West Michigan to document the Urban Native Relocation Program by conducting oral histories, digitizing primary source materials, and partnering with local organizations. Shell-Weiss, Benefiel, and McKee, in their article "We Are All Teachers: A Collaborative Approach to Digital Collection Development," eloquently summarize the project as "a model not just for collaborative collection development but also for community engagement," as these collections "add to the diversity of perspectives represented in their [the library's] holdings." ${ }^{\prime 11}$ The project builds relationships with the community beyond the institution and invites community knowledge into the canon of the academic library. Shell-Weiss et al. are clear that this project intends not only to document, but also to give voice and platform to, the community and ultimately to channel this information to power Native Studies scholarship and curricula, thereby creating new knowledge. ${ }^{32}$

\section{Methods}

Rather than limit the study to a single department within academic libraries, such as archives or special collections, the researchers chose to invite responses from anyone employed in an academic library in order to capture a wide, bird's-eye view of the current landscape of library-community collection development partnerships. For example, in some libraries, perhaps subject or liaison librarians are working with their academic units on community collaborations that generate new materials for the library's circulating collection; institutional repository (IR) managers might ingest unique community collections into the IR; technical services departments might perform original cataloging on the items; and/or perhaps reference and instruction librarians incorporate the materials into classroom settings. By inviting responses regardless of one's title or position, the study could unfold without preconceptions of which personnel and departments were most likely involved in the work; if the study had targeted one entity only, such as acquisitions, work in other areas may have been missed. This approach also allowed respondents to report on their library's and archive's activities even if they were not directly involved in the work, in order to mitigate cases where those who were involved did not respond. The researchers recognize that academic librarianship and archival work are distinct, but there is overlap insofar as archives typically operate within the context of the parent library, as part and parcel of the whole.

This study, vetted by the researchers' institutional review board, employed a mixed methodology. Researchers administered a 20-question electronic survey via Qualtrics to relevant library electronic discussion lists (see table 1) and incentivized its completion by the option to enter one's email address for a $\$ 100$ gift card drawing. (Appendix A presents the survey instrument, the questions of which were developed from the authors' own experiences working with the local lowriding community on the San Diego Lowrider Archival Project to document the history of the movement in the city and surrounding region.) The survey, a mix of open- and closed-ended questions, contained basic demographic questions about the respondent's institution and position, followed by questions asking whether/how the respondent's academic library currently engages in collaborative collection development with its local public community, when and why the work initially began, and how they 
would describe the community population(s) and materials involved in the project(s). If the respondent indicated that their library did not engage in this work, the survey asked why, and whether their library had any future plans to pursue it. Information identifying specific persons and institutions has been removed from results presented below.

\begin{tabular}{|l|l|}
\hline \multicolumn{2}{|c|}{ Listservs on Which the Authors Solicited Survey Respondents } \\
\hline Electronic Discussion List (Listserv) & Listserv Address \\
\hline $\begin{array}{l}\text { ACRL Digital Scholarship Section (DSS) Digital Humanities Discussion } \\
\text { Group (ALA) }\end{array}$ & dss-dh_dg@lists.ala.org \\
\hline ACRL Scholarly Communication (ALA) & scholcomm@lists.ala.org \\
\hline ALCTS Acquisitions Section (ALA) & acqnet@lists.ala.org \\
\hline ALCTS Collection Management Section (ALA) & colldv@lists.ala.org \\
\hline ALCTS Preservation Administrators'Interest Group (ALA) & padg@lists.ala.org \\
\hline College Libraries Section List (ALA) & collib-I@lists.ala.org \\
\hline Electronic Resources in Libraries List & eril-l@lists.eril-l.org \\
\hline Library and Information Technology Association List (ALA) & lita-l@lists.ala.org \\
\hline OCLC-Cataloging & oclc-cat@oclclists.org \\
\hline $\begin{array}{l}\text { SCORE-CARL IG: Scholarly Communication and Open Resources for } \\
\text { Education (SCORE) }\end{array}$ & score@listserv.carl-acrl.org \\
\hline Serials in Libraries Discussion Forum (NASIG) & \\
\hline Sharing and Transforming Access to Resources Section (STARS) (ALA) & serialst@simplelists.com \\
\hline University Libraries Section List (ALA) & stars-I@lists.ala.org \\
\hline
\end{tabular}

At the conclusion of the survey, respondents whose libraries are presently involved in collaborative collection development with the local community could indicate that they were available for a follow-up interview with the researchers to provide greater detail about the project's vision, genesis, development, and future direction. The interview was designed as an opportunity for participants to bring attention to their work, voice their experiences and recommendations, and spark a national conversation on the evolution and diversification of collection development practices. (Appendix B lists the interview questions; like the survey, the interview questions grew out of the authors' own experiences working on a collaborative collection development project.) The researchers also sought to interview a member of the library's local public community, a person identified and recommended by the library respondent due to their heavy involvement in the work, to gain a multifaceted view of the library-community collaborative collection development experience. (Appendix C contains the community member's interview questions, which parallel those of the library interview.) Due to health and safety concerns related to COVID-19, researchers conducted interviews virtually via Zoom. A case study featuring Georgia College and State University in Milledgeville, Georgia, is presented in the results section below.

\section{Results}

Survey

An initial 145 survey responses were received; but, after removing responses in which institu- 
tions were not clearly identified, were located outside the United States, or were duplicated, the viable total responses were reduced to 118 . These 118 respondents were employees at United States academic libraries, with a wide variety of geographic locations and institutions represented. The highest percentage were from doctoral universities (34\%) as classified by Carnegie, followed closely by master's colleges or universities (31\%). Thirty-two percent (32\%) of the total reported that their institution is located in a town/city/metro area with a population under 50,000, while 20 percent are located in an area with more than a million people.

When asked to identify the single category that best described their position, 31 percent classified themselves as faculty librarians, 20 percent as department heads/chairs, 18 percent as nonfaculty librarians, 14 percent as director/dean, 11 percent archivists, 3 percent as support/paraprofessional, and 3 percent as other. It is important to note that respondents self-identified as librarians (either faculty or nonfaculty) more than four times as often as archivists, suggesting that the work of collecting and curating community materials is not limited to archives and archivists but intersects with librarianship as well. In addition to this classification, respondents were required to provide their position title. Figure 1 is a word cloud that represents the frequency of terms (greater frequency is indicated by larger font size) occurring in these titles. The top five most frequently occurring terms were "Librarian," with 53 occurrences, followed by "Collections" with 29, "Special" with 22, "Head" with 21), and "Services" with 19. (Two terms were removed from the pool because they were so specific they would have jeopardized the respondents' anonymity.)

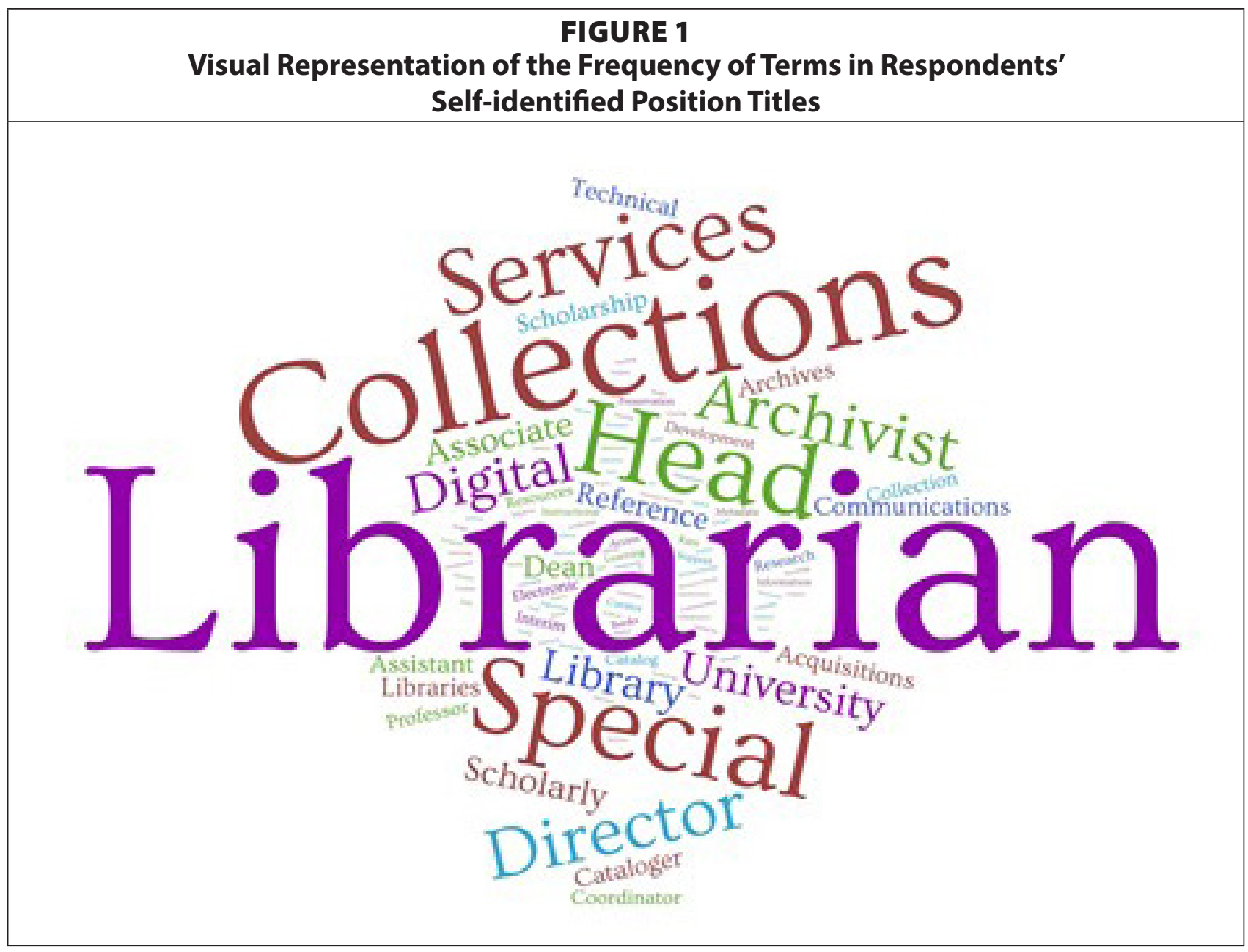


Figure 2 illustrates respondents' answers to the survey's central question: Does your library collaborate (or has it collaborated) with the local community on collections work (development/curation/preservation)? Significantly-and perhaps surprisingly-more than three quarters of respondents answered affirmatively.

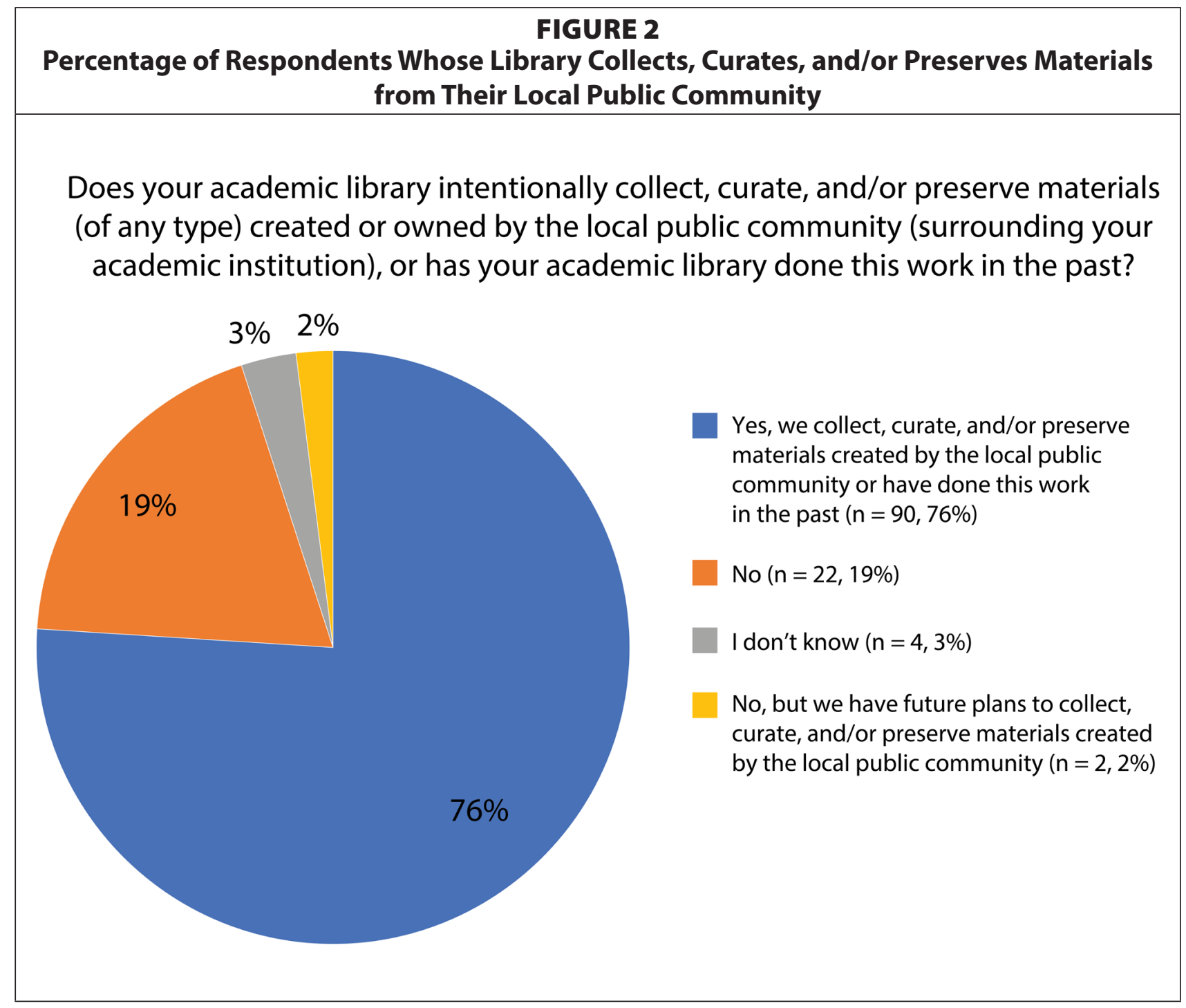

After completing this core question, 55 respondents exited the survey, with the remaining 63 completing the rest. When asked how long their library has been doing this work, 42 (67\%) of the 63 indicated that it began over a decade ago. One respondent commented, "Archiving these materials has been incredibly significant to the Libraries and the Archives for decades." Another said, "Our college was founded at the same time our town was founded; the town's history and our college history are inextricably linked since the early 1800s. Therefore, we have been collecting materials from our community for nearly 180 years." For a small number (5), the effort is less than two years old: "This is a fledgling initiative for us but ties strongly to our campus mission and vision," one wrote, while another offered, "We are a relatively new (3 years old) archive in the university library and are excited to involved [sic] the community and grow the collections so that the area is represented." 


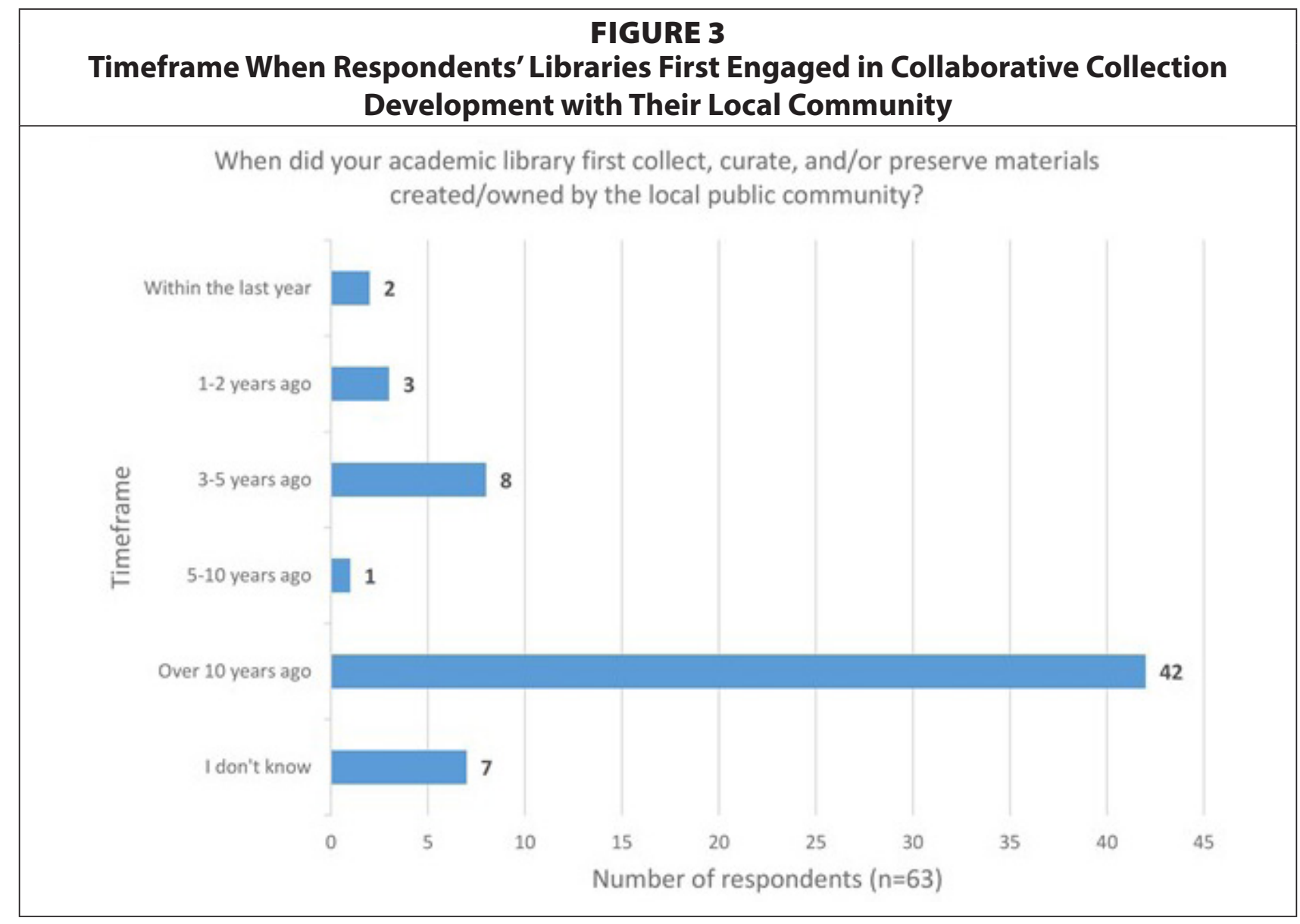

When asked to identify why their library does this work, respondents most frequently indicated its inclusion in their library's collection development policy or plan, followed equally by inclusion in their library's strategic plan and a request by their local public community. Figure 4 shows this breakdown. In their comments, respondents expounded on the factors driving these collaborations. Some referred to a responsibility to preserve the materials, lest they be lost forever. Others cited support for student and faculty research, as the materials provide rich learning experiences, as well as long-standing relationships between the institution and the local community. Some situate the work within their broader institutional context: for example, "We consider it part of our mandate, as the flagship institution of our state, to collect materials about the region."

Fifty-seven (57) respondents supplied qualitative information about the nature of their collaborative collection development work - for example, the history/origins of the project(s), the materials (type, format, content), their workflows and processes, and the demographics of the communities with whom they work. This data revealed a wide, diverse range of unique projects; here are some of them:

- "We partnered with the natural science community and considered ourselves the best local option for collecting local data - about specimens, coastal conditions, local population/demographic shifts, and formed a data portal."

- "There is an ongoing research project led by a faculty library [sic] to document a regional theater. Their items have been digitized and placed in the University's institutional repository." 


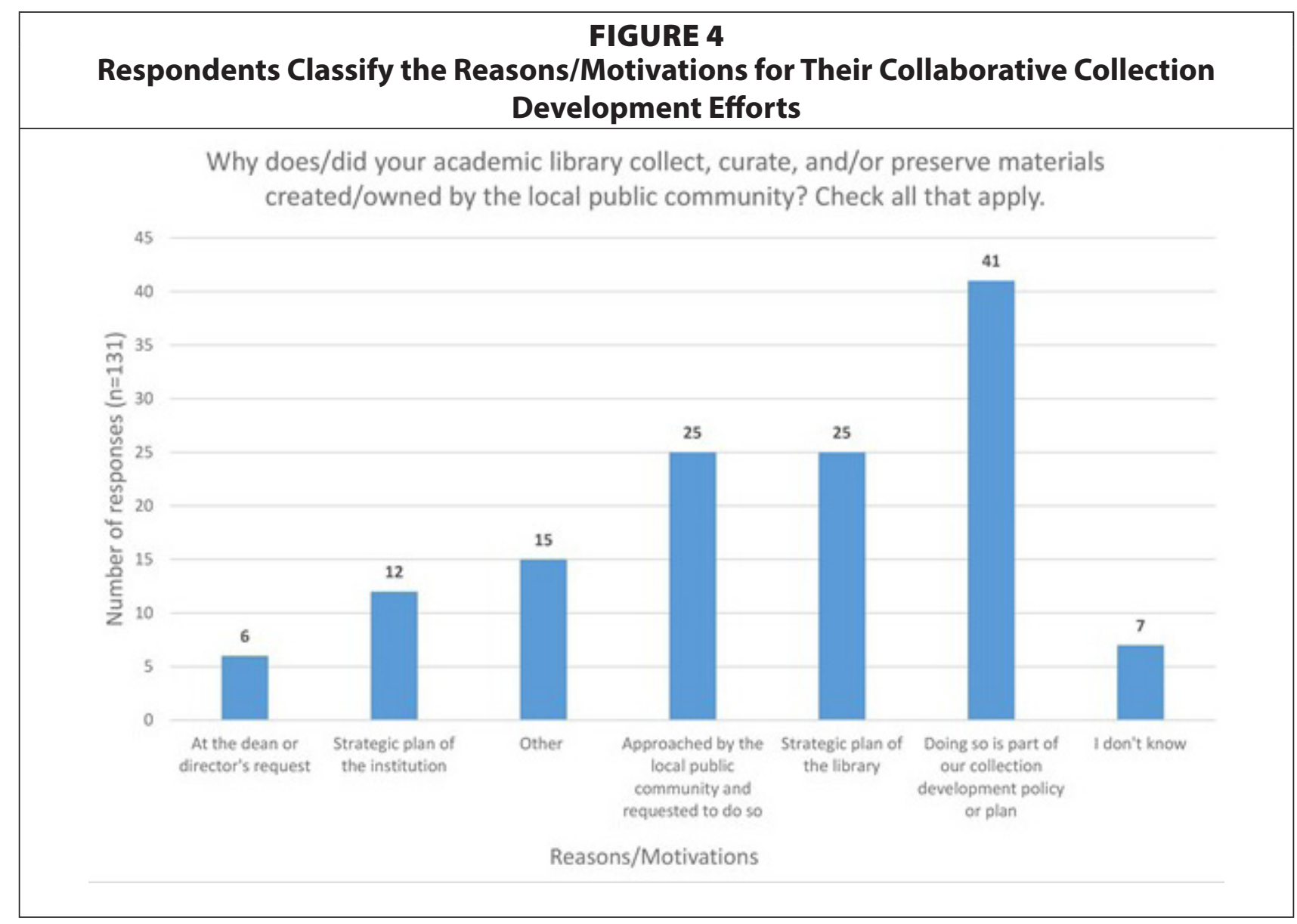

- "The materials were collected at one day events for a history harvest. Format was usually photos and digitized on the spot. New workflows are being developed so the community can submit materials directly to the institutional repository."

- "Our mission is to document the history and people of the local area so we accept donated collections, and actively seek them. In addition, we conduct oral history interviews locally to curate representative collections about our city and region."

- "In the latter part of the 20th century and continuing today, the library collects local government documents, including budgets, financial reports, grand jury reports, environmental impact reports, and climate action reports."

- "We have a circulating music collection (primarily CDs) of musicians/bands/solo acts that have either a small or large connection to the city of Milwaukee."

- "[Our library] collects materials by and about Riverside and San Bernardino counties as part of its larger collection development plan. These materials may be placed in the circulating collection and/or Special Collections and University Archives. While books are my primary collecting format, the Library is open to other formats as well."

- "We do web crawling of some local community blogs that focus on University events as well as Twitter accounts unaffiliated with the University for the same reasons."

For all their diversity, many of the projects emphasize historical documentation of local communities and organizations, ostensibly to capture and reveal a more complete picture of their establishment, development, growth, and change. In some cases, the projects have an explicit connection between the university and the local public community, such as current 
collaborations between faculty members or units on campus and specific community populations or organizations, while in others the connection is less precisely articulated. The materials themselves are extremely varied and dependent on the specific project and institution's focus. They include books, manuscripts, images, video, audio, posters, signage, art, data, family and personal papers, genealogical documents, oral histories, CDs, cassette tapes, church records, newspaper clippings, scrapbooks, diaries, letters, brochures, pamphlets, zines, maps, ledgers, meeting minutes, vital records, realia, local government documents, directories, and more. It is important to note that the majority, though not all, of the collections described are archival, historical in nature with preservation goals forefront. But some are more contemporary and are made available in the circulating stacks or in other ways, such as "exhibitions to highlight these materials." One respondent wrote that they routinely confront "the decision of whether to put such books in the stacks or archives." The trend toward archival materials is evident in figure 5, which depicts respondents' classification of the types of materials they collect, curate, and/or preserve.

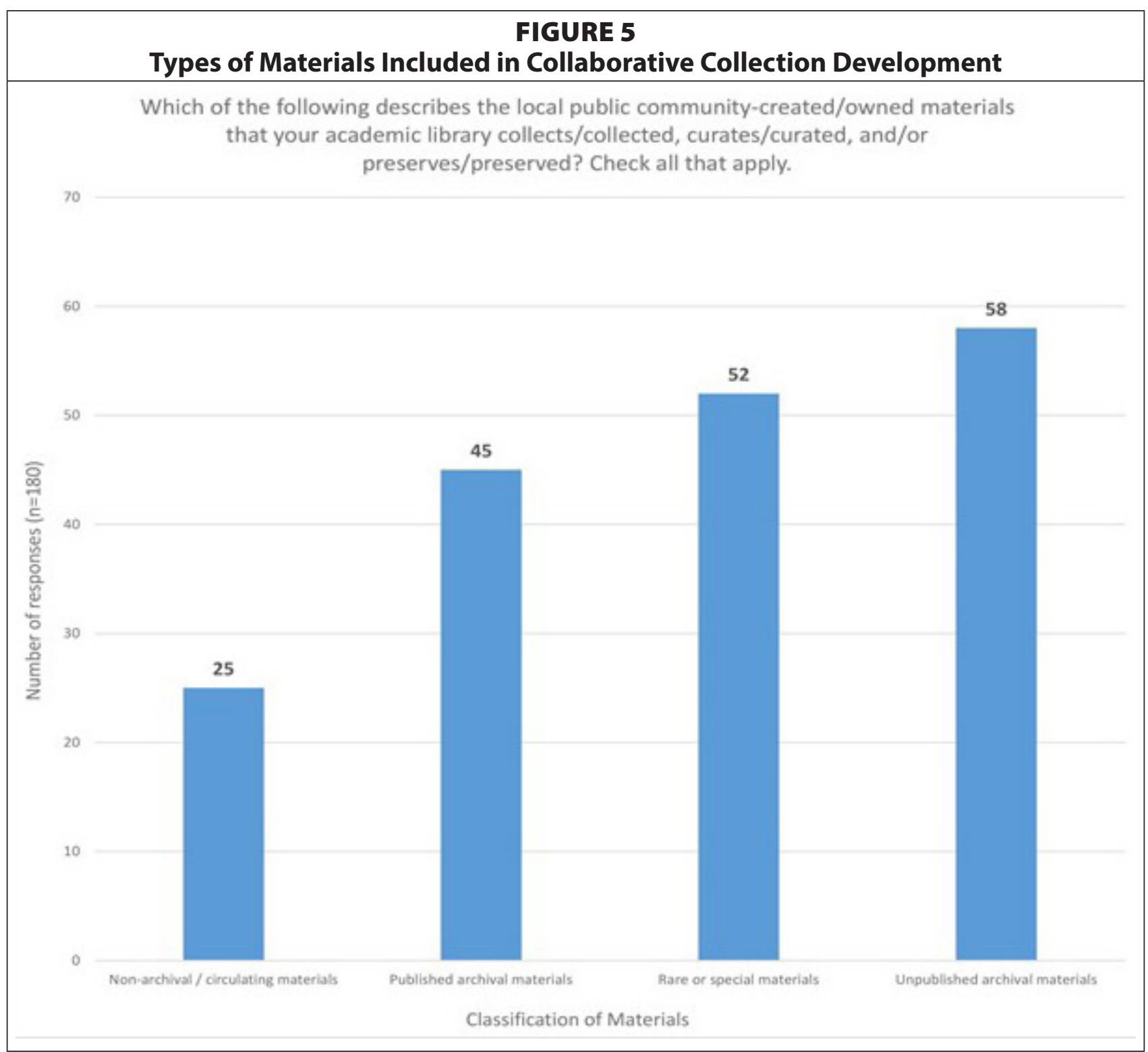


Like the materials, the populations with whom respondents partner on collaborative collection development are diverse. The survey asked, "Is the local public community population(s) with whom your academic library has worked to collect, curate, and/or preserve their materials a minority or underrepresented population within your town or city? If yes, please elaborate." Thirty-six respondents (57\%) answered "yes," while $19(30 \%)$ answered "no," and 8 (13\%) indicated they did not know. (See figure 6.) Qualitative responses provided greater details about the populations. In some cases, they are religious groups (such as Jewish or Quaker communities), while in others, they are racial or ethnic minorities (such as Indigenous or Latinx communities). Respondents emphasized the importance of giving voice to historically underrepresented communities, displaced populations, women, and people of color. In one representative example, a respondent wrote, "I live in one of the whitest states in the country, but I'm proud of my library's efforts to preserve the works and voices of all aspects of the community. Patrons are often pleasantly surprised by the breadth of our collections."

Not all respondents are engaged in collaborative collection development. Figure 7 depicts reasons expressed why respondents' libraries do not collect, curate, and/or preserve materials created by their local public community. The most often cited reason was that such work is not part of their library's collection development policy or plan (20, or $21 \%)$, followed closely by space $(15$, or $16 \%)$, staffing (14, or $15 \%)$, and budget and time constraints (each 13, or $14 \%$ ). Respondents described a host of challenges:

- "We don't have the dedicated staff or the equipment available to do it. We have won a grant that will hopefully allow us to do this finally."

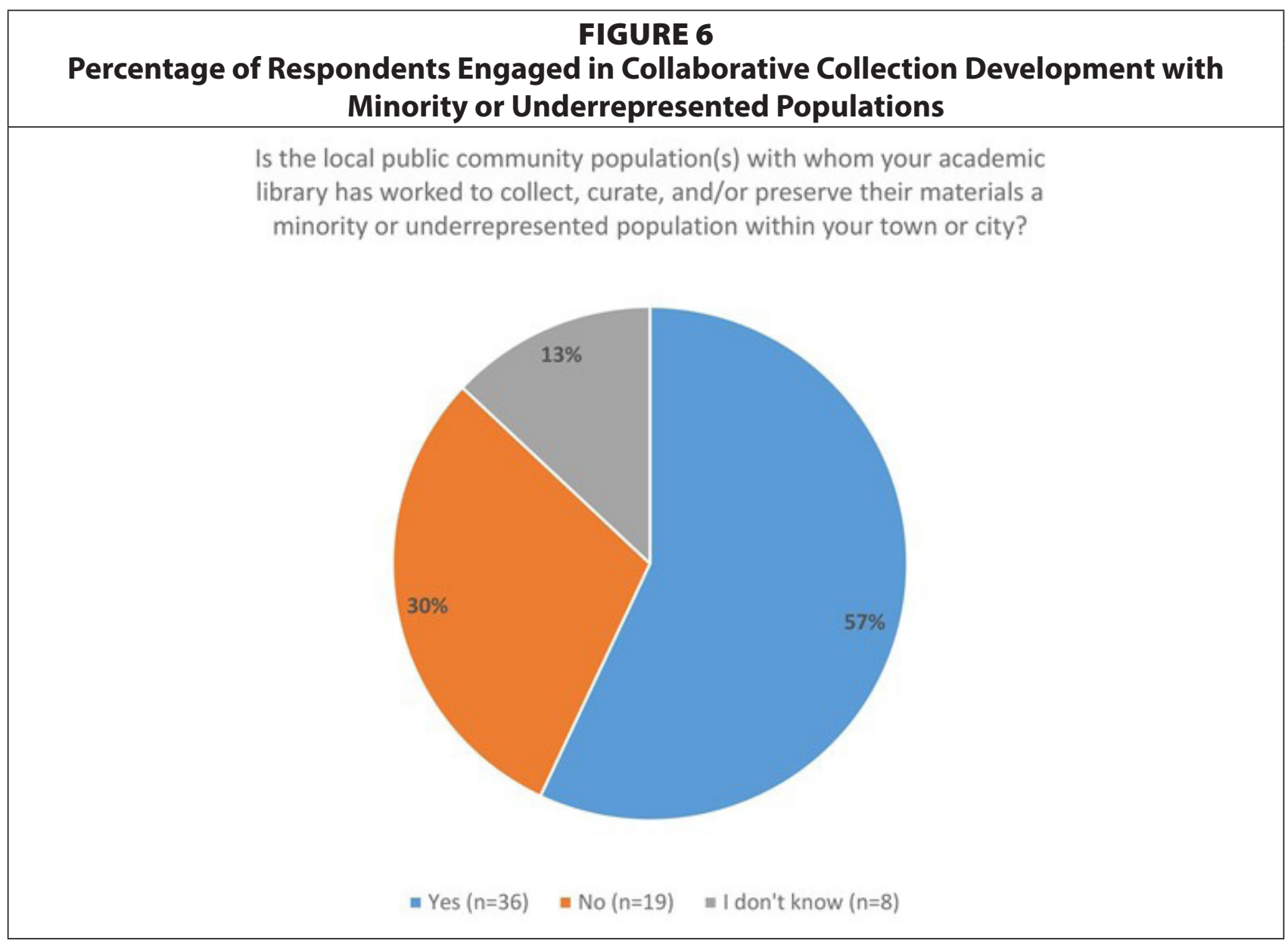


- " $\quad .$. it was not sustainable and we were not successful because of the workload."

- "It requires a lot of patience, time, developing procedures, workarounds but can be very beneficial for the local research community."

- "Over the 50 years of institutional life the strategic plans of campus and library have been challenged by personnel changes, the vagaries of public financial support, larger university goals, technology changes, and the needs of campus and community. Throughout this time, no one plan was followed and the archives grew from assorted projects rather than planning. Even today local efforts are disjointed ... The physical facility is space limited, especially as library space is procured for other academic endeavors."

- "It can be difficult, as a University Special Collections, to adhere to the collecting mandate set by the administration, while also leaving room for materials that may be slightly outside this scope, but that would be beneficial to collect as they do reflect our local population ... We also have limited room within our Vault, so cannot collect everything brought to us by the community. We also do not have a dedicated preservationist."

- "Although I have a degree in archives as well as in library science, the archiving activities definitely take a back seat to library work, and I cannot spend more than a few hours a week on them."

Despite the obstacles, most respondents $(76 \%)$ nonetheless have found ways to do the work of collaborative collection development. One such respondent was Holly Croft, Digital Archivist at Georgia College (GC) \& State University, who shared, "We have recently hired a community engagement archivist to focus on collecting materials from our underrepresented

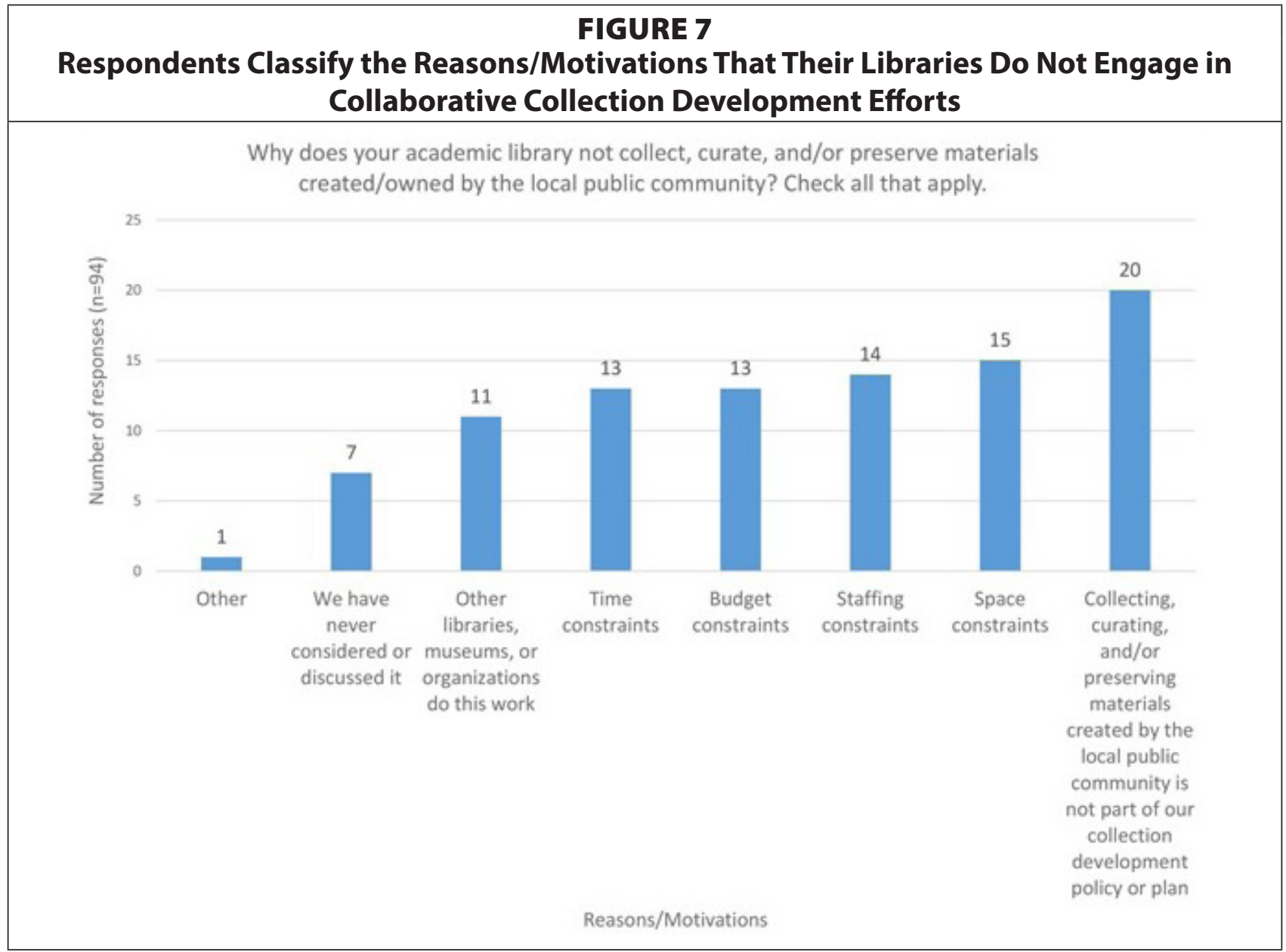


communities in the local area." This action-combining community engagement, collection development, and underrepresented communities - aligned so closely with the research agenda at hand that the researchers promptly contacted Holly and her team at GC to request interviews. While the GC interviews were not the first-researchers had also interviewed a respondent from another institution - their projects were unique in that they were already well underway: not only had grants been received, but community digitization efforts and workshops had taken place. They had the experience necessary to reflect on what had worked well and what posed a challenge. Moreover, they had a local community member involved in the projects who agreed to be interviewed. For these reasons, researchers chose to profile GC as a specific example of an academic library engaged in collaborative collection development with its local communities.

\section{Case Study: Georgia College E State University (Milledgeville, Georgia)}

Georgia College \& State University is a four-year, public liberal arts school with an approximate enrollment of 6,000 undergraduates and 1,000 graduate students. ${ }^{33}$ The institution is located in Milledgeville, a community of fewer than 20,000 residents in central Georgia. In its strategic plan, the institution notes its Carnegie Community Engagement classification. ${ }^{34}$

In two separate virtual interviews, Croft and Jessamyn Swan, whose title "Community Engagement Archivist" reflects a deep institutional commitment to this work, described the Ina Dillard Russell Library's efforts to collect, curate, and preserve Milledgeville's local community history and knowledge. Croft noted that GC's leadership - in particular, GC President Dr. Steve M. Dorman, Interim Library Director Dr. Shaundra Walker, and Associate Director for Special Collections Nancy Davis Bray - has been exceptionally committed to the library's community engagement efforts, explaining that this support "has influenced the way that Special Collections has been able to collect." ${ }^{35}$ According to the homepage of the Special Collections website, the department's mission is first and foremost to "serve the middle Georgia region by: 1) documenting the history and culture of Milledgeville/Baldwin County and its contiguous counties and, 2) by ensuring that the lives and experiences of our diverse communities receive historical recognition and representation." 36 Croft herself views collaborative collection development with the Milledgeville community as a responsibility of the college to the town. She used the term "allyship" to describe the type of relationship the Russell Library aims to cultivate with the local community. ${ }^{37}$

In their interviews, Croft and Swan described three distinct college-community collaborative collection development endeavors, each guided by a community advisory board. A third interview with Melvin Baymon Sr., a Georgia College alum and leader in Milledgeville's African American Baptist community, provided additional insight into one of those endeavors, the "Common Heritage" project. ${ }^{38}$

\section{Common Heritage: Documenting Milledgeville's African American History} In his interview, Baymon recalled his serendipitous involvement with "Common Heritage." A few years ago, he and his son Jamal, who was then 24 years old, began exploring both their own family history and the early history of their El Bethel Baptist Church, used historically as an educational site when the local school burned down. They wanted to establish an archive; they even had a church-owned property to house the materials. Around the same time, in the fall of 2018, Baymon attended a community gathering in which representatives from the 
college shared their desire to document and preserve the town's African American history. "We were looking for direction, and looking for a partner," he said of his church's archiving efforts, so this meeting felt fortuitous. ${ }^{39}$ His son, excited about the partnership, encouraged him to join forces with the college.

Funded by a $\$ 12,000$ grant from the National Endowment for the Humanities, "Common Heritage" seeks to preserve and share the region's African American history and heritage. ${ }^{40}$ Notably, in an interview with the local newspaper the Union-Recorder, Interim Library Director Shaundra Walker centers knowledge diversity at the heart of this work: "The whole gist of this project is about recognizing the knowledge that exists in the community and amplifying it and elevating it." ${ }^{41}$ The project originally grew out of two endeavors: former city manager, Mr. Barry Jarrett, convened a group to collect oral histories, while Dr. Walker established the groundwork to procure physical documents. (See figure 8.) The two efforts merged into one, and today the oral history group acts as a community advisory board for library-community partnerships. ${ }^{42}$ In a series of "harvest days" held at local community sites, community residents brought personal artifacts - such as photographs and documents - where the items were scanned and returned to their owners. ${ }^{43}$ (See figure 9.) Participants received digital copies of their items and were asked to grant permission for the digitized materials to be added to online collections that ultimately would be shared with the Digital Library of Georgia.

\section{FIGURE 8}

From bottom left, clockwise: Former Russell Library employee David Dawha, library employees Tanya Darden and Evan Leavitt, and Interim Library Director Dr. Shaundra Walker peruse local historical materials. Photo credit: Anna Leavitt. Reprinted with permission.

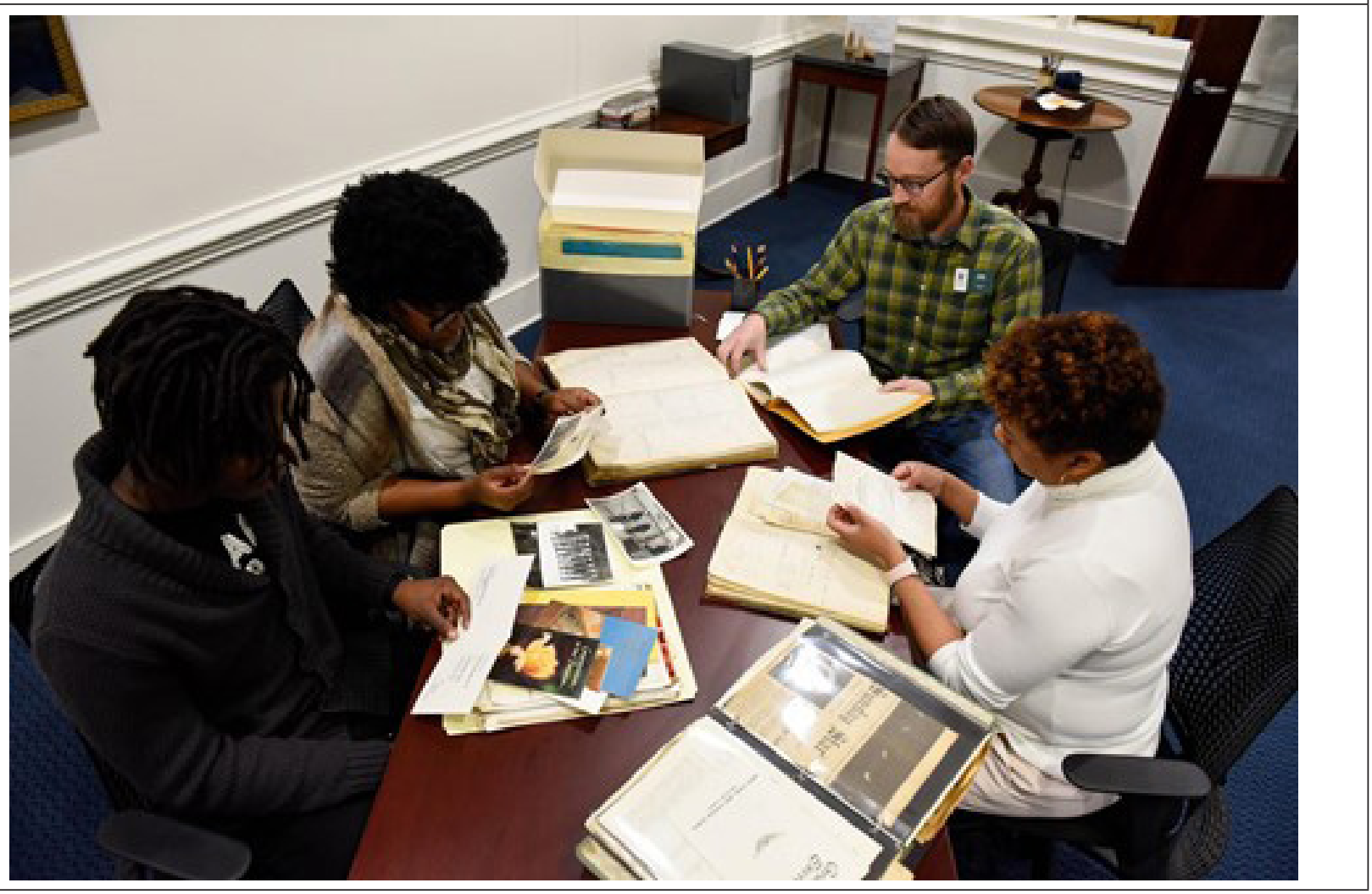




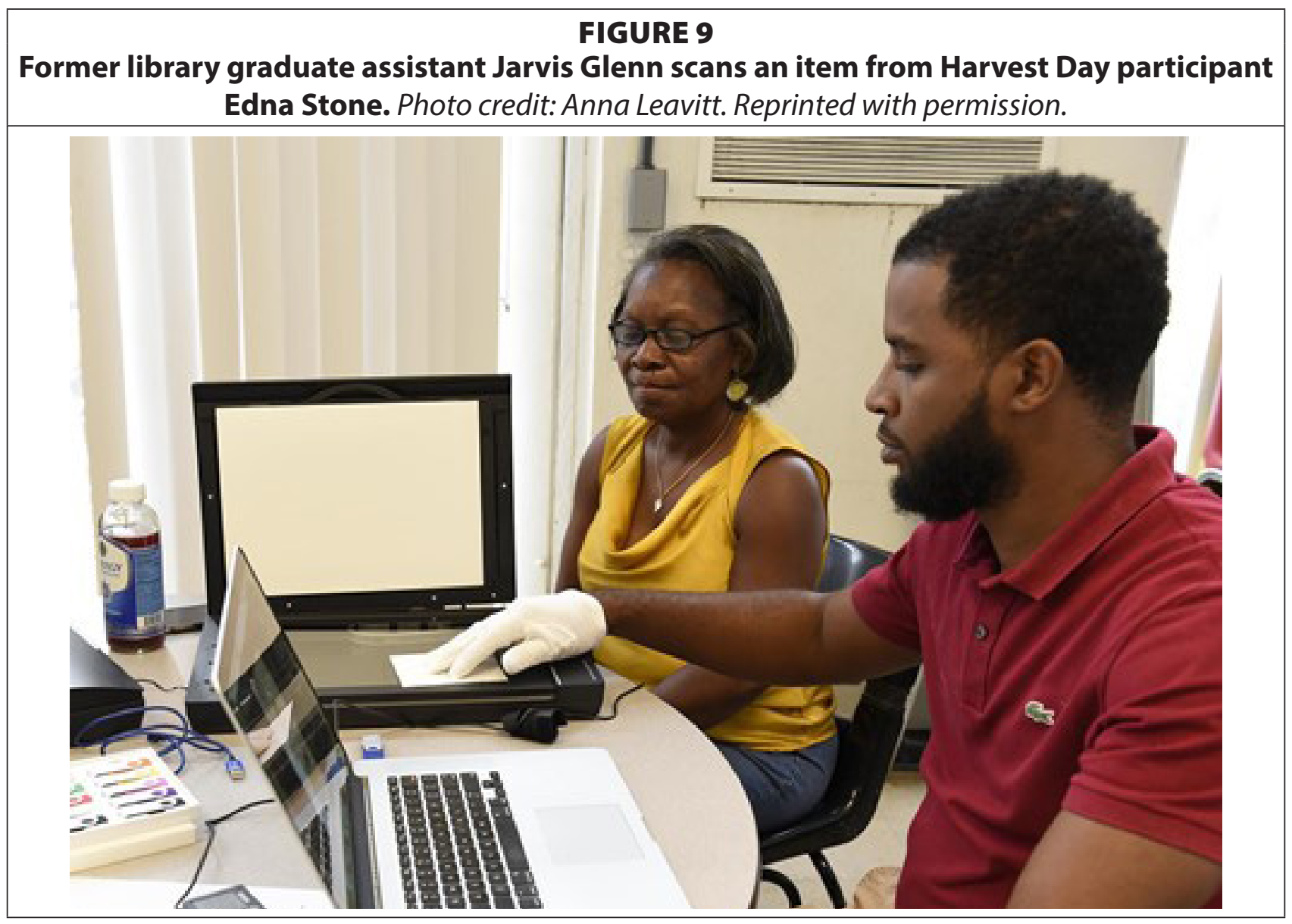

As part of the project, the library also offered an historic preservation workshop for community members and mounted a panel discussion featuring local historians alongside an academic expert on historic African American schools. ${ }^{44}$ (See figure 10.) Baymon emphasized the significance of these events, as they conveyed to the community the college's commitment to partnering with them. He appreciated the way that library representatives shared skills, knowledge, and tools and provided community members with new learning opportunities. This "giving back" was particularly important because, although GC is quite old (founded in 1889), Baymon characterized its relationship with the local African American community as relatively new. ${ }^{45}$

Baymon is passionate about the project and described the joy of working alongside local experts and historians, such as author James Finney, who in 2010 published the book The Making of Milledgeville: The Pictorial History of Baldwin County. ${ }^{46}$ On the other hand, he found that the most challenging aspect was getting people to follow through on their promises to contribute their materials. He encountered hesitation among some and discovered that championing the project's ultimate aims - to unearth and celebrate the vital contributions of the Black community to the region's history - was critical in garnering support and participation. Another challenge was the onset of COVID-19. On March 7, 2020, a community harvest day was held. The project was gaining momentum, Baymon said. ${ }^{47}$ And then the pandemic struck. Progress came to a halt. Still, he is optimistic about the future and has many goals he hopes the project will achieve. He describes how crucial it is to tell the stories of all parts of 


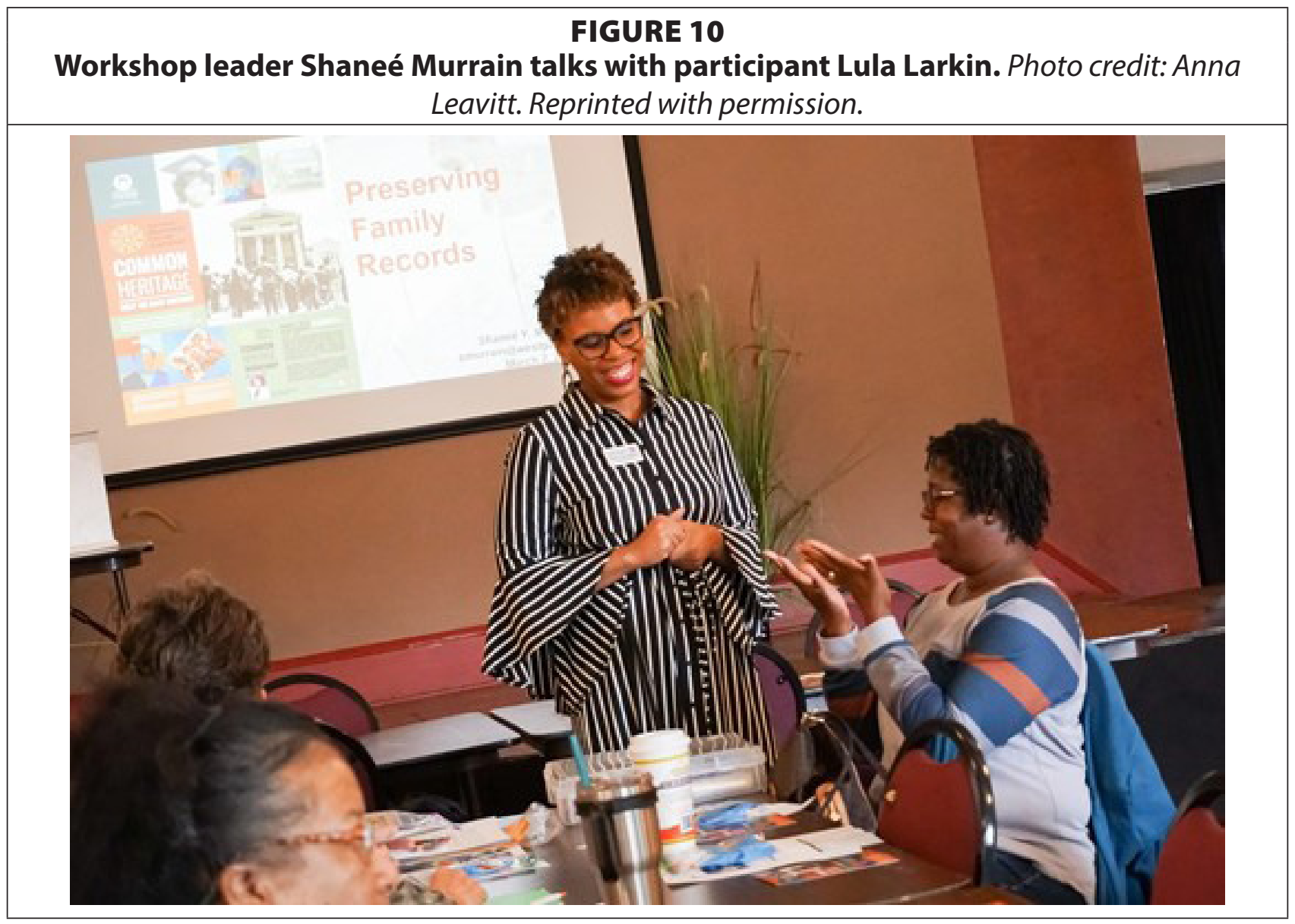

the community, as doing so instills pride in residents and helps them feel connected to their past. "I want young people to access it, to be inspired, to find that they and their family have a story, and that they matter. There are many unsung heroes, and by finding them, you find yourself." 48

\section{Remembering Central State Hospital (CSH): A Community Memory Project}

Currently underway, the second project, a partnership with the public Twin Lakes Library System (TLLS), originally began when Stephen Houser, the Director of TLLS, approached Croft during her third week on the job. ${ }^{49}$ Together, GC and TLLS applied for and received a nearly $\$ 50,000$ Institute of Museum and Library Services (IMLS) grant for "Remembering Central State Hospital (CSH): A Community Memory Project." ${ }^{50}$ The hospital, founded in 1842 but now closed, was "once the world's largest mental institution" and an integral part of Milledgeville and its surrounding community. ${ }^{51}$ The project seeks to collect oral histories by conducting interviews with former hospital employees (and potentially former patients) and to harvest digital copies of artifacts possessed by community members, ultimately to record memories "from local community members, who can tell a story that is not often told when we speak about our town." ${ }^{22}$ Facilitated by core team members Croft, Swan, Houser, and Russell Library's Manager of Facilities Operations \& Planning Evan Leavitt, "Remembering CSH" seeks to build greater awareness and knowledge of mental health and "to give neurodiverse individuals the opportunity to tell their stories, to frame their stories in a context that promotes 
understanding and compassion, and to encourage our community to explore their connections to CSH." ${ }^{53}$ Once complete, the final product will be shared through GC's institutional repository ("Knowledge Box") and the Digital Library of Georgia, as well as physical and digital exhibits and a day-long symposium during Mental Health Awareness month in 2022.

\section{The Seventh Circle Chronicles}

Swan began her appointment as Community Engagement Archivist in October 2019; during her interview for the position, she pitched a social justice, community engagement project called the "Seventh Circle Chronicles," named after Dante's Inferno, that would give voice, through the collection of oral memoirs, to three "invisible minority" groups in rural midGeorgia: LGBTQ+ individuals, domestic violence survivors, and inmates convicted of violent crimes. ${ }^{54}$ In an unpublished handbook Swan is preparing on the philosophical underpinnings of the project, she writes:

Like most archives that contain holdings from the modernist era of professional practice, the majority of our holdings tends to reflect the perspective of one demographic: straight white men of middle class or higher economic status ...The Seventh Circle Chronicles project will collectively canvass an estimated $24.5 \%$ of our population. It will be the latest in a series of initiatives hosted by this institution to the end of diversifying our holdings and in doing so, better representing our actual-diverse-population of stakeholders. ${ }^{55}$

Swan hopes the project will "validate the experiences of people living in a social underworld" and "open and democratize" the archive to all members of the surrounding communities. ${ }^{56}$ The physical recordings and transcripts generated by the project will be housed in Special Collections, and digital copies will be made available online. She emphasizes the importance of sensitivity to privacy concerns, involving community participants only at their own comfort level, and acknowledges that anonymity, redaction, and terms of moratorium will be necessary in some cases.

\section{Discussion}

The purpose of this study was to explore whether and how academic libraries and archives are partnering with their local public communities to collect, curate, and/or preserve communitycreated knowledge, particularly nontraditional forms of knowledge historically excluded from the academy; to examine the benefits, opportunities, and challenges of doing so; and to challenge and encourage academic libraries and archives to explore connections between collection development and community engagement. This study confirms that academic libraries and archives are collecting, curating, and preserving knowledge and memory from their local public communities - particularly minority or underrepresented populations - and offers tangible evidence of the opening within the academy, described previously by Chan et al., to knowledge held by those traditionally excluded from scholarly conversations. ${ }^{57}$

This work of collaborative collection development is happening across many different institutional and community settings; it is not highly correlated with institutional classification or town/city/metro size, though in most cases $(67 \%)$ the work has been underway for a decade or more. In their reflections and interviews, respondents articulated the wide variety 
these collaborative collections and partnerships take, including the vast array of materials involved, the diverse populations with whom they partner, and the many challenges that slow or inhibit the work. The majority of the work is happening specifically within archives departments; respondents logged more than twice as many occurrences of unpublished archival material as nonarchival/circulating material in their collaborative collection development efforts. Further research and exploration are needed on whether and how archives are prepared to undertake this work, what additional support they need, as well as how other departments within a library can contribute to this work.

In nearly a third of cases (31\%), the library's collection development policy or plan motivates the work. This finding suggests that codifying collaborative university-community collection development into official library policy is an important component of establishing and supporting the work. An example of a collections policy that integrates community engagement is MIT's “Creating a Social Justice Mindset: Diversity, Inclusion, and Social Justice in the Collections Directorate of the MIT Libraries." 58 The policy contextualizes the work of collection development within a broader responsibility to dismantle inequities in power and privilege within scholarly discourse and knowledge production. Calling for "representation of marginalized perspectives" and "community outreach and inclusion," the policy explicitly seeks to "incorporate non-majority voices ...[and] deliberately acquire materials through non-traditional publication channels." ${ }^{59}$ In addition to library policies and plans, academic libraries should tie this work to their parent institution's strategic plan, mission, or goals, if the parent prioritizes engaged scholarship (for example, those institutions with the "Community Engagement" Carnegie classification). Engaging in work that explicitly supports the parent's commitments and strategic direction is an important way for academic libraries and archives to articulate their value, gain esteem, and attract resources. ${ }^{60}$

Additional areas of research not addressed but prompted by this study include issues such as: processing considerations, access issues, copyright and intellectual property concerns, building relationships and trust among community partners, relationships between existing community archives and academic libraries, communities' rights to decline participation, privacy concerns, outreach strategies, obtaining institutional and external support, making room for this work among competing priorities, and tactics for tying the work to broader library and institutional missions and goals. A particularly pressing area for further investigation includes the connections among collaborative collection development, community-engaged scholarship, and student learning. Several survey respondents mentioned how the materials are used to support student research. For example:

Archiving these materials has been incredibly significant to the Libraries and the Archives for decades. Community members, faculty members, undergraduate and graduate students, international scholars, members of the media, etc. have all made extensive use of the collection. Our students and faculty frequently use the Archives to inform community-engaged scholarship.

Inviting locally produced forms of knowledge into academic libraries-whether in the form of archival content and/or circulating materials - provides students (and faculty) the opportunity to interact with new and different kinds of information and to engage with new and different sources. This incentive is especially relevant to the "Authority Is Constructed 
and Contextual" frame of ACRL's Framework for Information Literacy for Higher Education (2016), which seeks to develop in learners an understanding of the nuances of determining a source's authority and expertise and strives to cultivate their ability to "question traditional notions of granting authority and recognize the value of diverse ideas and worldviews." ${ }^{61}$ Integrating history, memory, and knowledge from local communities, especially historically marginalized groups, into the library and-ideally - the curriculum, provides students with a more comprehensive and critical view of the topic at hand. It gives voice to those who have been silenced or overlooked in academia in the past, enriches the educational experience of today's students, and supports social justice efforts. As Porterfield summarizes: "With concentrated efforts to collect underrepresented voices in the archival record ...repositories are uniquely situated to teach information literacy skills ... in a way that promotes social change." ${ }^{\prime 2}$ Much has been written about the ways in which primary sources and unique holdings in academic archives and special collections can support student learning, ${ }^{63}$ but research is lacking on whether, and how, academic libraries are specifically using unique collections from their own local communities to provide new learning environments. One impressive example that emerged from this study is at the University of the Pacific, where an interdisciplinary and interdepartmental (the Library; History; Art; Computer Science; Geological and Environmental Sciences) partnership with the local Filipino community resulted in a virtual, interactive model of the California city of Stockton's Little Manila district in the mid-twentieth century, before it was razed to build a crosstown freeway. The final products of this project have become part of both the university curriculum and the library's collection, as well as serving as a teaching tool for local schools. ${ }^{64}$

Finally, COVID-19 poses special challenges for this work. In many cases, outreach and personal connections were key to successful partnerships, but, now that physical contact and face-to-face interactions pose potential danger to one's health, will this work be as effective in a virtual environment? How can libraries cultivate relationships with members of local communities during the pandemic? What new approaches and processes can move the work forward?

\section{Conclusion}

As scholars and activists call for wider diversity and inclusivity in definitions of knowledge, and academia prioritizes collaborative, community-engaged scholarship, new opportunities arise for academic libraries and archives to support these values through collection development commitments and practices. Despite challenges, academic libraries and archives are working in a wide variety of ways to collect, curate, and preserve unique forms of knowledge produced by their local public communities. In many cases, these efforts seek to give voice to underrepresented or marginalized populations whose expertise and ways of knowing have been excluded historically from the canon of scholarly knowledge. There are many issues and considerations connected to this work, and additional research is needed, particularly regarding how engagement with local community collections impacts student learning. Libraries and archives committed to collecting, curating, and preserving local community knowledge can draw inspiration from institutions currently involved in this work (such as the Ina Dillard Russell Library at Georgia College), establish it as a priority within their own official collection development policy or plan, and attract attention and resources from their parent institution by connecting it to broader institutional mission, vision, and goals. 


\section{APPENDIX A \\ Survey Instrument}

\section{Collaborative Collection Development: Academic Libraries and their Local Public Communities}

Hello, My name is Amanda Y. Makula. I am a faculty member at Copley Library at the University of San Diego, San Diego, CA. My co-investigator Laura S. Turner and I are conducting a research study funded by an ACRL Scholarly Communications Research Grant (www.ala.org/acrl/ awards/researchawards/scholcommgrants) and we would like to invite you to participate if you work in an academic library. We plan to publish the results of this research and share it at a professional library conference.

The purpose of this study is to learn if and why academic libraries and their archives are intentionally collecting, curating, and/or preserving materials - of any type-created or owned by their local public community.

If you decide to participate, you will complete one online survey that takes up to 15 minutes. You will be asked things like: "Does your academic library intentionally collect, curate, and/or preserve materials (of any type) created or owned by the local public community (surrounding your academic institution), or has your academic library done this in the past?"

You will also be asked a few questions about yourself and your institution, such as your institution's name and Carnegie Classification, your role at the institution, and the population of the town or city in which your institution is located.

This study involves no more risk than the risks you encounter in daily life.

In the published results from this research, qualitative responses, while not attributed to specific individuals, may be identifiable by the nature of the project(s) and/or materials they describe. We will keep the study data for a minimum of eight years.

There is no compensation for taking part in this survey, but you will have the opportunity at the end of the survey to provide your email address to be entered into a drawing for a $\$ 100$ gift card.

Additionally, if your academic library has collected, curated, and/or preserved materials created or owned by the local public community, you will have the opportunity to volunteer for a follow-up in-person interview with the researchers. Interview participation requires that a member of the local public community with whom you have collaborated also be interviewed separately for their perspective. You will both receive a \$100 gift card for your participation.

Taking part in this study is entirely optional. Choosing not to participate will have no effect on any benefits to which you are entitled. You may also quit being in the study at any time 
or decide not to answer any specific questions. Should you decide to participate, please print out a copy of this page for future reference.

I am happy to answer any questions you may have about the study. You may contact me at (619) 260-6850 or amakula@sandiego.edu. You can also contact Laura S. Turner at (619) 260-2365 or lauraturner@sandiego.edu. If you would like to participate, please acknowledge your consent below and then begin the survey. The survey will close at midnight on Friday, January 31.

Thank you for your time.

Amanda Y. Makula

Q2 I consent to participate in this survey.

$\square$ Yes

Q3 Institution name:

Q4 What is the Carnegie Classification of your institution?

$\square$ Doctoral University

$\square$ Doctoral/Professional University

- Master's College or University

$\square$ Baccalaureate College

$\square$ Baccalaureate/Associate's College

$\square$ Associate's College

- Special Focus Two-Year

$\square$ Special Focus Four-Year

$\square \quad$ Tribal College

Q5 What is your position title?

Q6 Which of the following best fits your position title?

$\square$ Director/Dean

$\square$ Department Head/Chair

$\square$ Faculty Librarian

$\square$ Nonfaculty Librarian

$\square$ Archivist

$\square$ Support/Paraprofessional

$\square$ Other (please specify below):

Q7 What is the population of the town, city, or metro area in which your institution is located?

口 $0-50,000$

50,000-100,000

$\square \quad 100,000-250,000$

$250,000-500,000$

$500,000-1,000,000$

More than $1,000,000$ 
Q8 Does your academic library intentionally collect, curate, and/or preserve materials (of any type) created or owned by the local public community (surrounding your academic institution), or has your academic library done this work in the past?

- Yes, we collect, curate, and/or preserve materials created by the local public community, or have done this work in the past

- No, but we have future plans to collect, curate, and/or preserve materials created by the local public community

$\square$ No

I don't know

Display This Question:

If Does your academic library intentionally collect, curate, and/or preserve materials (of any type)... $=Y e s$, we collect, curate, and/or preserve materials created by the local public community, or have done this work in the past

Q9 Which of the following activities describe your academic library's engagement with materials created/owned by the local public community? Check all that apply.

口 We collect/have collected local public community-created/owned materials

$\square$ We curate/have curated local public community-created/owned materials

- We preserve/have preserved local public community-created/owned materials

Display This Question:

If Does your academic library intentionally collect, curate, and/or preserve materials (of any type)... $=Y e s$, we collect, curate, and/or preserve materials created by the local public community, or have done this work in the past

Q10 When did your academic library first collect, curate, and/or preserve materials created/ owned by the local public community?

$\square$ Within the last year

ㅁ 1-2 years ago

ㄴ 3-5 years ago

ㄴ 5 -10 years ago

More than 10 years ago

口 I don't know

Display This Question:

If Does your academic library intentionally collect, curate, and/or preserve materials (of any type)... = Yes, we collect, curate, and/or preserve materials created by the local public community, or have done this work in the past

Q11 Why does/did your academic library collect, curate, and/or preserve materials created/ owned by the local public community? Check all that apply. 
$\square \quad$ Strategic plan of the institution

$\square$ Strategic plan of the library

$\square$ Doing so is part of our collection development policy or plan

$\square \quad$ At the dean or director's request

$\square$ Approached by the local public community and requested to do so

$\square$ I don't know

$\square$ Other (please specify below):

\section{Display This Question:}

If Does your academic library intentionally collect, curate, and/or preserve materials (of any type)... $=Y$ es, we collect, curate, and/or preserve materials created by the local public community, or have done this work in the past

Q12 What can you tell us about your academic library's collecting, curating, and/or preserving materials created/owned by the local public community? For example:

$\square \quad$ the demographics of the local public community population(s) whose materials your academic library collects/collected, curates/curated, and/or preserves/preserved

$\square \quad$ the format, type, and/or content of the materials

$\square$ the processes and/or workflows employed for collecting, curating, and/or preserving the materials

\section{Display This Question:}

If Does your academic library intentionally collect, curate, and/or preserve materials (of any type)... $=Y e s$, we collect, curate, and/or preserve materials created by the local public community, or have done this work in the past

Q13 Is the local public community population(s) with whom your academic library has worked to collect, curate, and/or preserve their materials a minority or underrepresented population within your town or city?

If yes, please elaborate.
$\square$ Yes
$\square \quad$ No
I don't know 
Display This Question:

If Does your academic library intentionally collect, curate, and/or preserve materials (of any type)... = Yes, we collect, curate, and/or preserve materials created by the local public community, or have done this work in the past

Q14 Which of the following describes the local public community-created/owned materials that your academic library collects/collected, curates/curated, and/or preserves/preserved? Check all that apply.

$\square$ Nonarchival/circulating materials

$\square \quad$ Published archival materials

$\square \quad$ Unpublished archival materials

$\square \quad$ Rare or special materials

Display This Question:

If Does your academic library intentionally collect, curate, and/or preserve materials (of any type)... $=Y e s$, we collect, curate, and/or preserve materials created by the local public community, or have done this work in the past

Q15 Is there anything else you'd like to tell us about your academic library's collecting, curating, and/or preserving materials created/owned by the local public community?

Display This Question:

If Does your academic library intentionally collect, curate, and/or preserve materials (of any type)... = No

Q16 Why does your academic library not collect, curate, and/or preserve materials created/ owned by the local public community? Check all that apply.

$\square \quad$ Time constraints

$\square$ Budget constraints

$\square$ Space constraints

$\square$ Staffing constraints

$\square$ Collecting, curating, and/or preserving materials created by the local public community is not part of our collection development policy or plan

$\square$ Other libraries, museums, or organizations do this work

$\square$ We have never considered or discussed it 
$\square$ Concerns about intellectual property issues

$\square \quad$ I don't know

$\square$ Other (please specify below):

Display This Question:

If Does your academic library intentionally collect, curate, and/or preserve materials (of any type) $\ldots=$ No, but we have future plans to collect, curate, and/or preserve materials created by the local public community

Q17 Why does your academic library plan to collect, curate, and/or preserve materials created/ owned by the local public community? Check all that apply.

$\square$ Strategic plan of the institution

$\square \quad$ Strategic plan of the library

$\square$ Doing so is part of our collection development policy or plan

$\square$ At the dean or director's request

$\square$ Approached by the local public community and requested to do so

$\square$ I don't know

$\square$ Other (please specify below):

Display This Question:

If Does your academic library intentionally collect, curate, and/or preserve materials (of any type)... $=$ No, but we have future plans to collect, curate, and/or preserve materials created by the local public community

Q18 What can you tell us about your academic library's plans for collecting, curating, and/or preserving materials created/owned by the local public community? For example:

$\square$ the demographics of the local public community population(s) whose materials your academic library plans to collect, curate, and/or preserve

$\square$ the format, type, and/or content of the materials

$\square$ the processes and/or workflows your library will employ for collecting, curating, and/or preserving the materials

Display This Question:

If Does your academic library intentionally collect, curate, and/or preserve materials (of any type)... = Yes, we collect, curate, and/or preserve materials created by the local public community, or have done this work in the past 
Q19 Because your academic library collects, curates, and/or preserves materials created/owned by the local public community (or has done so in the past), you are eligible to participate in a follow-up in-person interview with one of the researchers of this study. Participation requires that a member of the local public community population with whom you collaborated also be interviewed separately for their perspective. You will both receive a $\$ 100$ gift card for your participation. The researcher would come to your location so no travel is required on your part. Please provide your name and email address if you would like to be considered for an interview. Thank you!

\begin{tabular}{|l|l|}
\hline & \\
\hline Your Name & \\
\hline Your Email Address & \\
\hline
\end{tabular}

Q20 Thank you for completing this survey!

If you would like to be entered into a drawing for a $\$ 100$ gift card, please enter your email address: 


\section{APPENDIX B Interview Questions for Library Representative}

When did your library begin collecting, curating, and/or preserving materials created by the local public community? How did this partnership come about?

How many such projects with the local public community do you have? Please describe each.

How would you describe the philosophical or theoretical underpinnings of the project(s)?

Who initiated the project(s)? Does that person(s) work in your academic library, in a community organization, or somewhere else? Please provide their title(s).

Who was involved throughout the project(s), and what were their roles? Please include everyone, both those in your library and those in the local public community.

What kind of work at your library goes into maintaining the project(s)? Who does this work?

Have you had to relinquish other work or projects to have time and resources to devote to this project(s)?

Did/do you receive institutional support or grant funding for the project(s), or do you plan to seek institutional support and/or grant funding? If so, please describe.

What does a "typical day" in the life of this project(s) look like?

What have been the greatest challenges of this project(s)?

Would you do anything differently if you could? If so, what and why?

What have been the greatest opportunities or rewards of this project(s)?

How do you define or measure whether or not the project(s) has been successful?

What are your future plans for this project(s)? What do you envision it will look like in 5, 10, or 20 years?

What else would you like people to know about this project(s) and/or partnership?

What questions do you have for me? 
APPENDIX C

\section{Interview Questions for Community Representative}

When did you begin working with $\mathrm{X}$ library on this project(s)? How did this partnership come about?

How many such projects with $\mathrm{X}$ library do you have? Please describe each.

How would you describe the philosophical or theoretical underpinnings of the project(s)?

Who initiated the project? Does that person(s) work in your local community, in X library, or somewhere else? Please provide their title(s).

Who was involved throughout the project, and what were their roles? Please include everyone, both those in the local public community and in X library.

What kind of work in your community or organization goes into maintaining the project?

Who does this work?

Have you had to relinquish other work or projects to have time and resources to devote to this project(s)?

Did/do you receive any funding or support for the project(s) (for instance, from a parent organization, from a grant, or other source), or do you plan to seek funding or support? If so, please describe.

What does a "typical day" in the life of this project(s) look like?

What have been the greatest challenges of this project(s)?

Would you do anything differently if you could? If so, what and why?

What have been the greatest opportunities or rewards of this project(s)?

How do you define or measure whether or not the project(s) has been successful?

What are your future plans for this project(s)? What do you envision it will look like in 5, 10, or 20 years?

What else would you like people to know about this project(s) and/or partnership?

What questions do you have for me?

\section{Notes}

1. Barbara Fister, “Liberating Knowledge: A Librarian's Manifesto for Change,” Thought E Action (Fall 2010): 89, https://barbarafister.net/ThoughtandAction.pdf.

2. Deborah K. Boudewyns and Shannon L. Klug, "Collection Development Strategies for Community Engagement," Collection Management 39, no. 2/3 (July 3, 2014): 145, https://doi.org/10.1080/01462679.2014.890994.

3. Helen N. Levenson, "Nimble Collection Development Policies: An Achievable Goal," Library Resources $\mathcal{E}$ Technical Services 63, no. 4 (October 2019): 206-19, https://doi.org/10.5860/lrts.63n4.206.

4. Tony Horava and Michael Levine-Clark, "Current Trends in Collection Development Practices and Policies," Collection Building 35, no. 4 (October 2016): 98, https://doi.org/10.1108/CB-09-2016-0025. 
5. Leslie Chan et al., "Open Science beyond Open Access, for and with Communities: A Step Towards the Decolonization of Knowledge," (Ottawa, Canada: Canadian Commission for UNESCO's IdeaLab, 2020), i-18, https://doi.org/10.5281/zenodo.3946773.

6. Chan et al., “Open Science Beyond Open Access, for and with Communities,” 10.

7. Brown University Swearer Center, "CUEI: College \& University Engagement Initiative: Defining Engaged Scholarship," https://www.brown.edu/swearer/lynton/defining-engaged-scholarship [accessed 29 April 2020].

8. Paul Wangoola, "Mpambo, the African Multiversity: A Philosophy to Rekindle the African Spirit," in Indigenous Knowledges in Global Contexts: Multiple Readings of our World, eds. George J. Sefa Dei, Dorothy Goldin Rosenberg, and Budd L. Hall (Toronto, ON: University of Toronto Publishing, 2000), 273.

9. Wangoola, "Mpambo, the African Multiversity."

10. Quoted in LaMont Jones, "Research Survey: Universities Highly Intentional about Community Engagement," Diverse: Issues in Higher Education (April 24, 2019), https://diverseeducation.com/article/144273/ [accessed 5 May 2020].

11. Brown University Swearer Center, "CUEI: College \& University Engagement Initiative: Community Engagement," https://www.brown.edu/swearer/carnegie/about [accessed 29 April 2020].

12. Carnegie Classification of Institutions of Higher Education, "Listings" (2020), https://carnegieclassifications.iu.edu/listings.php [accessed 29 April 2020].

13. Joshua J. Yates and Michaela Accardi, Field Guide for Urban University-Community Partnerships (University of Virginia: Thriving Cities Lab, Institute for Advanced Studies in Culture, 2019), 44, https://iasculture.org/ research/publications/thriving-cities-field-guide [accessed 4 April 2020].

14. Association of College \& Research Libraries (ACRL), "Open and Equitable Scholarly Communications: Creating a More Inclusive Future" (Chicago, IL: Association of College \& Research Libraries, 2019): 5, https:// doi.org/10.5860/acrl.1.

15. ACRL, "Open and Equitable Scholarly Communications," 20.

16. ACRL, "Open and Equitable Scholarly Communications."

17. Mary M. Somerville and Dana EchoHawk, "Recuerdos Hablados/Memories Spoken: Toward the Co-Creation of Digital Knowledge with Community Significance," Library Trends 59, no. 4 (2011): 659-60, https://doi.org/10.1353/ lib.2011.0018.

18. Peter E. Sidorko and Tina T. Yang, "Knowledge Exchange and Community Engagement: An Academic Library Perspective," Library Management 32, no. 6/7 (July 26, 2011): 386, https://doi.org/10.1108/01435121111158538.

19. Sidorko and Yang, "Knowledge Exchange and Community Engagement," 388.

20. Toong Tjiek Liauw (Aditya Nugraha), "Leadership Role of an Academic Library in Community Outreach: Surabaya Memory Project," Advances in Librarianship 38 (2014): 3, https://doi.org/10.1108/S0065-283020140000038004.

21. Liauw, "Leadership Role of an Academic Library in Community Outreach," 12.

22. Lynn C. Westney, "Conspicuous by Their Absence: Academic Librarians in the Engaged University," Reference \& User Services Quarterly 45, no. 3 (2006): 200, quoted in Toong Tjiek Liauw (Aditya Nugraha), "Leadership Role of an Academic Library in Community Outreach," 12.

23. Liauw, "Leadership Role of an Academic Library in Community Outreach," 12-13.

24. Alan Cho, "Bringing History to the Library: University-Community Engagement in the Academic Library," Computers in Libraries 31, no. 4 (May 1, 2011): 15-18.

25. Danielle Allard and Shawna Ferris, "Antiviolence and Marginalized Communities: Knowledge Creation, Community Mobilization, and Social Justice through a Participatory Archiving Approach," Library Trends 64, no. 2 (2015): 360, https://doi.org/10.1353/lib.2015.0043.

26. Allard and Ferris, "Antiviolence and Marginalized Communities," 362.

27. Allard and Ferris, "Antiviolence and Marginalized Communities," 371.

28. Caroline Daniels et al., "Saving All the Freaks on the Life Raft: Blending Documentation Strategy with Community Engagement to Build a Local Music Archives," American Archivist 78, no. 1 (March 2015): 247, https:// doi.org/10.17723/0360-9081.78.1.238.

29. Daniels et al., "Saving All the Freaks on the Life Raft," 247-48.

30. Joan D. Krizack, "Preserving the History of Diversity: One University's Efforts to Make Boston's History More Inclusive," RBM: A Journal of Rare Books, Manuscripts, and Cultural Heritage 8, no. 2 (September 1, 2007): 126, https://doi.org/10.5860/rbm.8.2.286.

31. Melanie Shell-Weiss, Annie Benefiel, and Kimberly McKee, "We Are All Teachers: A Collaborative Approach to Digital Collection Development," Collection Management 42, no. 3/4 (October 2, 2017): 317, https://doi.or g/10.1080/01462679.2017.1344597.

32. Shell-Weiss, Benefiel, and McKee, "We Are All Teachers," 333, 335.

33. Georgia College, "Future Students," https://www.gcsu.edu/future-students [accessed 24 June 2020] 
34. Georgia College, “Our Path to Preeminence: The 2016-2021 Georgia College Strategic Plan,” https://www. gcsu.edu/sites/files/page-assets/node-1315/attachments/2016_strategic_plan_to_preeminence_0.pdf [accessed 24 June 2020].

35. Holly Croft, personal communication, June 23, 2020.

36. Ina Dillard Russell Library, "Special Collections," http://libguides.gcsu.edu/c.php?g=388927\&p=2638867 [accessed 24 June 2020].

37. Croft, personal communication.

38. Melvin Baymon Sr., personal communication, August 7, 2020.

39. Baymon, personal communication.

40. Georgia College and State University, "Documenting Milledgeville's African American History," National Endowment for the Humanities (NEH) (2019), https://securegrants.neh.gov/publicquery/main. aspx?f=1\&gn=PY-263696-19 [accessed 24 June 2020].

41. "GC Grant Seeks to Preserve Local African-American History," Union-Recorder (February 22, 2019), https:// www.unionrecorder.com/news/gc-grant-seeks-to-preserve-local-african-american-history/article_485646a8-36bf11e9-87b8-531b9c122e0b.html [accessed 24 June 2020].

42. Croft, personal communication.

43. Georgia College, "Documenting Milledgeville's African American History."

44. Croft, personal communication.

45. Baymon, personal communication.

46. James Finney, The Making of Milledgeville: A Pictorial History of Baldwin County (Xlibris, 2010).

47. Baymon, personal communication.

48. Baymon, personal communication.

49. Croft, personal communication.

50. Twin Lakes Library System, "Remembering CSH: A Community Memory Project: Project Justification," Institute of Museum and Library Services (IMLS) (2020), https://www.imls.gov/sites/default/files//grants/app246130-ols-20/proposals/app-246130-ols-20-proposal.pdf [accessed 24 June 2020].

51. Twin Lakes Library System, "Remembering CSH."

52. Twin Lakes Library System, "Remembering CSH."

53. Twin Lakes Library System, "Remembering CSH."

54. Jessamyn Swan, personal communication, June 26, 2020.

55. Jessamyn Swan, "About the Chronicles" [unpublished manuscript], 2020.

56. Swan, personal communication.

57. Chan et al., "Open Science beyond Open Access, for and with Communities," 10.

58. Michelle Baildon et al., "Creating a Social Justice Mindset: Diversity, Inclusion, and Social Justice in the Collections Directorate of the MIT Libraries," Report (February 9, 2017), https://dspace.mit.edu/handle/1721.1/108771 [accessed 11 July 2020].

59. Baildon et al., “Creating a Social Justice Mindset," 13, 16.

60. Janet R. Cottrell, "What Are We Doing Here, Anyway? Tying Academic Library Goals to Institutional Mission," College \& Research Libraries Newws 72, no. 9 (October 1, 2011): 516-20, https://doi.org/10.5860/crln.72.9.8633; Brinley Franklin, "Surviving to Thriving: Advancing the Institutional Mission," Journal of Library Administration 52, no. 1 (January 2012): 94-107, https://doi.org/10.1080/01930826.2012.630244; Maggie Gallup Kopp, "Academic Libraries, Institutional Missions, and New Student Recruitment: A Case Study," Reference Services Review 41, no. 2 (June 7, 2013): 192-200, https://doi.org/10.1108/00907321311326192.

61. Association of College \& Research Libraries (ACRL), Framework for Information Literacy for Higher Education (Chicago, IL: Association of College \& Research Libraries, 2016), 4, www.ala.org/acrl/sites/ala.org.acrl/files/ content/issues/infolit/Framework_ILHE.pdf [accessed 11 July 2020].

62. Julie Porterfield, "Teaching Social Justice with Special Collections and Archives: Critical Information Literacy and Primary Source Analysis," in Social Justice and Activism in Libraries: Essays on Diversity and Change, eds. Su Epstein, Carol Smallwood, and Vera Gubnitskaia (Jefferson, NC: McFarland, 2019), 190.

63. Marcus Robyns, "The Archivist as Educator: Integrating Critical Thinking Skills into Historical Research Methods Instruction," American Archivist 64, no. 2 (September 2001): 363-84, https://doi.org/10.17723/ aarc.64.2.q4742x2324j10457; Peter Carini, "Archivists as Educators: Integrating Primary Sources into the Curriculum," Journal of Archival Organization 7, no. 1/2 (May 29, 2009): 41-50, https://doi.org/10.1080/15332740902892619; Magia G. Krause, "'It Makes History Alive for Them': The Role of Archivists and Special Collections Librarians in Instructing Undergraduates," Journal of Academic Librarianship 36, no. 5 (September 2010): 401-11, https://doi. org/10.1016/j.acalib.2010.06.004; Matthew Cook, "Build It and They Will Come: Integrating Unique Collections and Undergraduate Research," Collection Building 34, no. 4 (October 5, 2015): 128-33, https://doi.org/10.1108/CB- 
06-2015-0010; George P. Germek, "Starting Almost from Scratch: Developing Special Collections as a Teaching Tool in the Small Academic Library," College E Undergraduate Libraries 23, no. 4 (October 2016): 400-13, https:// doi.org/10.1080/10691316.2015.1028606; Tracy B. Grimm and Sharra Vostral, "Archive as Laboratory: Engaging STEM Students \& STEM Collections," Engineering Studies 11, no. 2 (May 4, 2019): 135-52, https://doi.org/10.1080/ 19378629.2019.1651731.

64. College of the Pacific, "Digital Delta Project Combines Art, History, Technology to Preserve Community's Legacy," College of the Pacific (blog, June 12, 2017), https://collegeofthepacific.wordpress.com/2017/06/12/digitaldelta-project/. 